\title{
Learning, Scholarship and Public Libraries in Pre and Colonial Sudan
}

\author{
Al haj Salim Mustafa PhD \\ Department of Social Science, AlHOSN University Abu Dhabi. UAE
}

doi: 10.19044/esj.2017.v13n17p54 URL:http://dx.doi.org/10.19044/esj.2017.v13n17p54

\begin{abstract}
Although the idea of providing public library services to the general public is basically a westernized concept, nevertheless the Sudan has a long tradition of learning and scholarship in which one could argue that an embryonic and rudimentary public library service of some sort had been established.

The purpose of this paper is to provide an historical overview of this learning and scholarship development and to explore the forces social, historical and political that led to the emergence of public libraries in pre and colonial Sudan. The historical research method was used to describe such forces employing mainly books, journal articles and to a lesser extent theses and dissertation. This will be followed by a discussion and conclusion.
\end{abstract}

Keywords: Public libraries, history, Sudan, colonialism

\section{Introduction}

Experience and common practice worldwide have shown that there are strong and significant links between education on the one hand and libraries on the other hand. Writing, reading and acquiring new knowledge and information are generally associated with the use of libraries.

\section{Methodology}

The study employs the historical method which has been described as "an attempt to learn from the past" (Moore, 1987, p.40). The intention of the method then is to record a sequence of events and presents and present a picture of development of something. The historical method was used in this paper to describe the social, educational, political and cultural forces that influenced the emergence of public libraries in the Sudan. It would be crucial for any future planning of public library development in the country to study past experience because it will no doubt impact the present and future library direction, performance and potential growth. Secondary sources were used 
extensively in this paper including books, journal articles, and reports and to a lesser extent theses and dissertations

\section{Sudan Geopolitics}

The Sudan is in terms of area an enormous country. The first feature which might strike anyone studying the country is the variety and diversity of its geographical features and the way they combine to together to produce a sequence of varied climates, cultures and way of production and life. The Sudan has sea, mountains, plains and rivers, forests and deserts. It is described as a cultural melting pot or a microcosm of Africa (Abdel-Hai, 1982).

The ethnic origins of the country's population are made up of Arab, Mediterranean and African elements. This mixture invariably gives the country a variety of cultures and languages and a blend of Arabic/Islamic and local cultures.

In 1821 Egypt conquered the Sudan and established some form of centralized administration. Before that the Sudan has no central administrative power or political entity, being largely governed by tribal leaders in isolated kingdoms such as the Funj (1504-1820) and Fur Sultanates .In 1881 a Sudanese religious leader the Mahdi defeated the Turco-Egyptian army and established for the first time in the modern history of the Sudan a national state known as The Mahdist state (1885-1898). In 1898 that state was defeated at the battle of Omdurman by Lord Kitchener who led an Anglo-Egyptian army to recapture the country. In 1899 an Anglo- Egyptian agreement concerning the Sudan was signed. That agreement ushered in an era of Anglo -Egyptian rule known as the condominium which last for fifty seven years represented the whole colonial period of the Sudan. In fact the Egyptian participation was nominal since "Egypt itself was under British control at the time” (Warburg, 1971).

In the early decades of colonial rule, all notion of Islam as a basis of political community, together with other traditional concepts of social organizations and attitudes towards political authority were discouraged. In their place a new pattern of modern political, cultural and educational orders were forcefully established (Abdel- Rahim, 1969).

Curiously, the British rulers, despite their attempts to modernize the Sudan did not embark upon establishing public libraries as they did in other African colonies such as Ghana as we shall discuss later in this paper.

\section{Learning and Scholarship in pre colonial Sudan}

Ancient Sudan or Nubia as it was known in early times has had contacts with the "Assyrians, pharaonic, Greek and Roman Civilizations as 
indicated by the writing of classical historians and geographers such as Herodotus and Strabo" (Shinnie, 1979).

The Nubian land has also played a significant part in African culture. Its unique location made it an ideal meeting for the Near Eastern/Mediterranean great civilizations on the one hand and African cultures on the other hand.

Writing, reading and the process of generating, collecting and dissemination of knowledge of graphic records had acquired a considerable vogue from very early times as most of the monuments and other historical evidence would reveal.

During the Christian era, which dominated Nubian land for nearly eight century, Sudanese Christian kingdoms such as Nobatia, Mugarra and Alowa developed a Christian civilization "closely akin to Byzantine civilization, Rome and the Ethiopian church” (Abdel-Hai, 1982) The great influence of Christian civilization however came from the Egypt where Christian culture was at its peak, notably in Alexandria where the acclaimed Alexandria library exists.

There is no tangible evidence to show that similar libraries were in existence in the Sudan during that period, however, it is believed that the area had a high level of culture as indicated by recent archaeological discoveries.

The turning point in the Sudan's history of learning and scholarship came with the advent of Islam in the $14^{\text {th }}$ century. Muslim/Arab culture entered the Sudan peacefully and through mingling and inter-marriage penetrated slowly into the social life of the people and by the $16^{\text {th }}$ century this culture became predominant in the Sudan.

The introduction of Arabic/Islamic culture into the Sudan can be said to have laid the foundation stone for the development of the contemporary Sudanese education and culture.

As early as the $14^{\text {th }}$ century the first type of organized education had started in the Sudan, when holy men and religious scholars came from different parts of the Islamic world, notably from Yemen, Baghdad and Maghreb (North Africa). Each of these scholars soon established his own small Islamic school or Khalwa to teach Quran and classical Arabic and Islamic sciences.

Until the turn of the 20th century, public libraries in their modern sense were probably nonexistent. However, in some parts of the pre-colonial Africa, including the Sudan, rudimentary public library services were in existence in the Khalawi or Qur'anic schools.

Jack Goody, writing about the literacy tradition and the existence of both books and libraries in Pre-colonial western Sudan described these Qur'anic schools as: 
“...untidy clusters of huts which although attracted little or no attention from contemporary travelers, never the less, contained and still do libraries of books, some of local origin but mostly emanating from north Africa and beyond" (Goody,1969,p.12).

The holy men have a very high and respected status in the society. In early Islamic Kingdoms Such as the Funj Islamic Sultanate, some of these holy men possessed considerable political influence and others were endowed with grants of land (Jackson, 1912)

The importance of the holy men was not derived solely from their abilities to teach and memorize the holy Qur'an, but also from the use made of their storage capabilities of books. For the latter every holy man was "a living library" or as described by one writer " $a$ veritable living encyclopedia and a proto-mobile library" (Amadi, 1981, p.67).

There is no evidence so far to support the existence of any type of organized libraries in their current modern forms in the Sudan during that period, however:

"Most of the past religious chiefs used to own small collections of books and manuscripts for their own reference and for their followers and students...They used to contact these books to seek relevant verdicts for solving social, economic and other problems on a religious basis" (Mamoun, 1972, p.28).

Most of these books were of Egyptian origin where scholarship, authorship and printing were available long ago, however handwritten books and manuscripts, including the holy Qur'an were produced locally. The written literacy tradition, indigenous authorship and the intellectual movement were generally rather slow, if not stagnant during the Islamic kingdoms period. From the whole of this period which spans over more than three centuries, very few writings have come down to us. They consist largely of religious works, poetry and to a lesser extent chronologies (Hassan, 1974; Bussyaly, 1963; Holt, 1962; Abu Salim, 1970).

The influence of Fugra or religious teachers working voluntarily in these schools was noticed and commended by the writings of the traveler. J.L. Burckhardt, who visited the Sudan in 1814 and left a vivid description of the Fugara and Ulama (scholars) in the town of Al-Dameer. He recorded for example the tidiness, regularity and good conditions of these Khalwas which attracted pupils from as far as western Africa. He also reported that the Fugara had many books on theology and law brought from Cairo (Burckhardt, 2011).

\section{Educational development in the colonial period (1820-1956)}

Modern westernized schooling started during the Turko- Egyptian rule (1820-1881). 
In 1853 the first primary school was established in Khartoum. This school which became known as the Khartoum Primary School was basically intended for the children of Turkish and Egyptian officials working in Sudan. The school did not survive for very long as it was closed shortly after its third year. However, by 1867 and 1868 primary schools were set up in Khartoum, Berber and Dongla. The pupils went into government services. The further history of these schools and one of two others which were started is obscure (Holt \&Daly, 1979).

Formal education did not resume until the coming of the Mahdist state when it opened its Mahdia School in the late 1880's at Omdurman. We do not have much information about this school except scattered references to it in Abu Salim's "History of Khartoum” (Abusalim,1971).From this source it appeared that the school offered slightly more than a Khalwa since its curriculum included mathematics and advanced Arabic language studies in addition to the teaching of Qur' an and classical Islamic studies.

With such limited educational facilities and massive illiteracy, one can hardly expect to find a library service to support the educational system or for the general public.

The real development of formal education and the impact of western ideas and western education upon Sudan, hence the establishment of libraries did not come until the establishment of the Gordon Memorial College (GMC) in 1902

The aims and objectives of education in the colonial period were best described by Sir James Currie, who was appointed as first director of education in the Sudan (1900):

"...to enable the masses to understand the element of the system of government, to train a small class of competent artisans and to provide a small administrative class for entry to the government service." (Holt \&Daly, 1979, p.123).

That policy was enhanced further by the feeling of some British officials in the Sudan that:

"Over education poses a greater threat to the country than did no education at all "(Beshir, 1969, p.41).

Clearly, in such a policy education has never been considered as being of value in itself. Rather it was a reflection of the needs of government departments for graduate and the prevailing administrative policy.

\section{Public libraries in Colonial period}

In the colonial Sudan as indeed in other parts of the colonized African countries, the concept of introducing public library services to the local inhabitants was not a priority for the colonial administration. 
Libraries, like educational institutions were considered a threat to colonialism because they would expose native people to different social and political ideas, thereby revealing the nakedness of colonial exploitation. For this reasons libraries were to be discouraged in all colonies.

Such a policy has been demonstrated in all frankness and honesty not only in the Sudan but also in other parts of the colonized Africa. The American librarian Milton Ferguson, who had been sent to survey South African libraries on behalf of the Carnegie Corporation of New York in 1928, noted that:

"...the white South African is willing for the native to cook his food and carry his books to and from the library, but he would feel that an end to his regime were at hand if the same servant were permitted to open these books and read therein" quoted in (Parker 1985,p.33).

R.F. Flood, a British Council Librarian, writing in 1951 observed that:

"The Gold Coast, Jamaica and East Africa - Kenya, Uganda and Tanganyika - have public library schemes adequately financed, planned and developed by experience librarians" (Flood, 1951,p.39).

Like the Sudan, all these territories were previously British Colonies with more or less similar socio-economic and educational backgrounds. The public libraries development mentioned by Flood was a result of long campaigns by individuals and institutions. Dedicated British librarians, interested British administrators, educational institutions such as the British Council, and Christian missionaries all had played a prominent role in setting up public libraries in these territories.

In the Sudan this was not the case, as with the exception of the British Council, none of the above mentioned organizations or individuals was able or willing to establish public libraries in the country.

For this reasons public library services were non-existent in the Sudan until the second half of the 1930's.

The first mention to the necessity of establishing public library service in the Sudan was a letter from the Administrative Secretary to the Grand Mufti (Judge) of the Sudan (1924) to inform him that the Sudan government has an intention to establish a public library service in commemoration of the Governor General Sir Lee Stack who was assassinated in Cairo in that year. The Administrative Secretary urged the Grand Mufti to write to the ulemas (learned men) to suggest book titles for the proposed library. Unfortunately nothing has materialized and no public library was established (Al-Tayeb, 1999).

In 1935, a prominent Sudanese intellectual wrote an article in the only periodical at the time calling for the necessity of establishing a public library from the money left from the will of the assassinated Governor 
General to be used for charity purposes such as public library and a museum. Plans for the public library were made, however at the last minute the government decided to establish a Medical Laboratory (Stack Medical laboratory) instead (Al-Tayeb 1999)

It appeared that the educated Sudanese were aware of the importance of libraries in enlightening the citizens. The graduate Congress has pressed hard to establish public libraries in the country. This was evident from the demands presented to the then prime Minister of Egypt Ali Maher Pasha when he visited the Sudan in 1940.

"The Egyptian government should undertake to establish an Arabic public library in Khartoum and furnish it with good collection of Arabic books in order to strengthen the cultural ties between the two sisterly countries "(Saeed, 1986, p.45).

It was reported also that the Sudan Delegate, an all party representatives who visited Cairo in 1946 to discuss the Sudan question with the Egyptian government had mentioned in a memorandum to the Egyptian government that there was no public library in the Sudan and that a prominent Sudanese gentleman had applied to establish a public library in Omdurman at his own expenses, but the government had refused to grant him the permission (Plumbe, 1950).

The first public library in the Sudan was established in Wad-Medani in 1947 by some educated Sudanese as "Purely Reference Collection used for private studies” (Plumbe, 1950) however by 1950 a borrowing service was introduced.

Another public library was established at about the same time in Omdurman by the British Council. That library in the words of Wilfred Plumbe was:

"an excellent small public library housed in an attractive room, gay with pictures, carpets and with comfortable chairs...with a collection of 4000 books, 300 pamphlets and 35 current periodicals” (Plumbe, 1950).

There has been a mention to public libraries being established in the Graduates clubs of Port Sudan and Al-Obied.

Some Europeans working in the Sudan had also set up their own small subscription libraries in Khartoum and Medani. Such libraries, of course, were not opened to the public, as they were exclusive libraries for whites and as such cannot be considered public libraries per se.

The Colonial Education Department had established in 1951 a public library in Omdurman to serve both the general public and schools in the area. The Omdurman Central Library as it was known played a significant role in public library development in the colonial and post-colonial eras, until its eventual and sad decline in the 1970's and 1980's. 
The most serious attempt to establish public library service was perhaps initiated by Sir Douglas Newbold the then Administrative Secretary who died prematurely in Khartoum in 1945. K.D.D. Henderson gave a detailed description of these efforts in his book: The making of the modern Sudan:

The idea of establishing a cultural centre in Khartoum goes back to 1937 when a group of British administrators and some Sudanese Affandeia (government employees) look into the possibilities of such project. The idea found an acceptance to Newbold the then Administrative Secretary. He suggested that the cultural centre should "consist of a social club with library, lecture room, and other amenities where Sudanese and British and members of the other segregated communities of Khartoum ... could meet and mix and exchange views" (Henderson, 1954, p.108).

Eventually, the centre constitution and regulation were made and the cultural centre was official opened on $25^{\text {th }}$ of April 1940 with a collection of around 1125English books and 280 Arabic books and an invaluable collection of the renowned Sudan Notes and Reports Journal volumes donated by the Editorial committee.

Newbold delivered the inaugural lecture to the Sudan Cultural Centre on 30 may1940 titled; The Human Side of Culture in which he summed up the goals of the centre in this words:

".... This cultural Centre...is a place, an out- of school and out- of college and out-of office place where educated people can not only polish up their minds... but humanize their minds, the apparatus, the equipment which they have at hand consists of a library, books and journals, of lecture and debate" (Henderson, 1954, p.408).

Other public libraries found during the colonial period were the municipality’s libraries usually in the Muderia (province) capital city.

In 1948, Dr A.H.Marshal Treasurer of Coventry City Council visited the Sudan to advice the Sudan government on the organization of local governments His report and recommendations granted a wide range of powers to the local councils that go along similar lines with the British local authority's duties and responsibilities. These duties and responsibilities included interalia, general and technical education, Adult education, clubs, reading rooms and libraries (Marshal, 1949)

The Medani public library mentioned above was probably the first library to be established as a direct result of Marshal Recommendation. The Blue Nile province Governor G. R.F. Bredin suggested to local council a public library which was passed by the council and the library was established in 1947. Al- Obied Municipality has also established a public library in 1953 followed by Atbra public library 1955 
The libraries mentioned above represent the sum total of public library services in the country during the colonial period. Up to the end of that period they remained:

"...small units, self contained and unable to draw upon book resources and professional skills other than that they possess themselves" (Plumbe, 1950, p.55)

The whole library development in colonial Sudan as indeed in the rest of Africa was best summed up by Holdsworth, thus:

"In Africa the pattern of library growth shows a progression from what one might call 'bread and butter' libraries, that is from libraries indispensable for the proper exercise of the functions of a state [the Colonialist Government] and the work of industry, trade and professional classes...through libraries of institutions for higher education to finally public libraries. One striking feature in Africa...is the preponderance of special, university and college libraries and the meagerness of public library provision" (Holdsworth, 1961, p.252).

From this narration of public library development during the colonial period, it would be safe to argue that any public library development during that period was a mere accident as there was no policy to develop them on a nation-wide basis as was the case in Ghana. (Evans, 1964) The emergence of strong indigenous political leaders in these countries such as Kwame Nkrumah in Ghana who supported the role of library services in development, the presence of dedicated expatriate librarians such as Miss Evelyn J. A. Evans in Ghana as well as the emergence of indigenous local librarians had all contributed considerably to the development of libraries in these countries. None of these factors appear to have been in evidence in the Sudan. Moreover there was no comprehensive library legislation, a national library or any other statutory body to coordinate library development in the country.

This failure can be attributed to a number of reasons: Firstly, The British Government was not really interested in the Sudan as a part of British Empire, being very big and very poor. Their main objective of keeping the Sudan under the crown was to control Egypt, and most importantly to stop other colonial powers from expansion in East Africa. As such no real interest in developing educational and social services, including libraries was shown by British administrators in the Sudan or at the colonial office in London. Moreover the inhabitants were often sick, thirsty, undernourished, illiterates and under these circumstances such things as water, food, security, medicine and Shelter were of primary importance than establishing public libraries.

Secondly, the Sudanese people, even the illiterate ones, were very conscious of their own culture and tradition. Islam and the Arabic language remained dominant despite the attempt to impose English as a second 
language and the discouragement of religious education. As most library materials were in English language and with a dearth of Arabic reading materials, the establishment of public libraries was viewed by colonial administration as unnecessary.

Thirdly, the Christian and other benevolent institutions failed to set up libraries in the Northern Sudan because the majority of people were Muslims. Any attempt to set up a missionary public library would have been met with suspicion and hostility. It is true that church missionaries were able to set up their own private libraries but establishing public libraries was not attempted.

Fourthly there were many ethnic groups and many spoken languages (over 100 languages spoken) and as such the lack of reading materials in vernacular languages was a hindrance to establishing public libraries even the Arabic- the language of the majority lacks such relevant materials.

\section{Conclusion}

As shown in this paper, public libraries in the Sudan didn't take off over the period under study. The paper demonstrates clearly that public library service development is one of stagnation, lack of recognition, coordination and was exceedingly slow and therefore falls far behind the public library development in other colonized African countries with similar history of colonial experience. As such any little development that has been made during that period was a mere accidental since there was no coherent and clear policy to develop such services.

\section{References:}

1. Abdel-Hai, M. (1982). Cultural policy in the Sudan. Paris, UNESCO.

2. Abdel-Rahim, M. (1969). Imperialism and nationalism in the Sudan. Oxford, Clarendon press.

3. Abusalim, Mohamed Ibrahim. (1970). Alharka Alfikrya Fi Almahdyia. Khartoum, KUP. (Arabic text)

4. Abusalim, Mohamed Ibrahim. (1971).Tarikh Al Khartoum. Khartoum, Dar Alfakr. (Arabic text)

5. Al-Tayeb, O.A. (1999). Nashaat Almaktabat Fi Al-Sudan. Unpublished MA. O.I.U. (Arabic Text).

6. Amadi, A.O. (1981).The emergence of a library tradition in pre and post-colonial Africa, International Library Review 13, 65-72

7. Beshir, Mohamed Omer.(1969).Educational development in Sudan. Oxford, Clarendon.

8. Burckhardt, J. L. (2011) Travels in Nubia. London, British Library, Historical Print Editions 
9. Bussayli, A. (1963) Makhatutat Katib Alshuna Fi Tarikh Alsudan. Cairo. (Arabic text)

10. Evans, Evelyn J. A. (1964). A tropical library service: the story of Ghana’s libraries. London, Deutsch.

11. Flood, R. A. (1951). Public Libraries in the colonies. London, Library Association.

12. Goody, Jack. (1968).Introduction. In Jack Goody(Ed), Literacy in traditional societies. Cambridge, Cambridge University Press.

13. Hassan, Y.F. (1974). Kitab Altabagat, edited by Y. F. Hassan. Khartoum, KUP. (Arabic Text)

14. Henderson. K. D.D. (1954).The making of the modern Sudan. London, Faber and Faber.

15. Holdsworth, H. (1961).University and special libraries and higher education in Africa. UNESCO Bulletin for Libraries 15,254-262

16. Holt, P. M.(1962) The Mahdist archives and related documents. Archives._5 1962, 193-200.

17. Holt, P. M. \& Daly, M.W. (1979). The history of the Sudan from the coming of Islam to the present day. London, Weidenfeld and Nicolson.

18. Jackson, H. C. (1912). Tooth of fire: Being some account of the ancient kingdom of Sinnar. Oxford, B.H.Blackwell.

19. Mamoun, Izz-Aldin. (1972).Past, present and possible future development of librarianship in the Sudan: in international librarianship: papers submitted to the 1971 IFLA Seminar for developing countries. London, Library Association.

20. Marshal, A. H. (1949). Report on local government in the Sudan. Khartoum.

21. Plumbe, Wilfred J. (1950).Sudan Libraries. South African Libraries $18,51-56$

22. Moore, N. (1987). How to do research? 2nd ed. London, Library Association.

23. Parker, J.S. (1985). UNESCO and library development planning. London, Library Association.

24. Saeed, B. M. (1986) Al-Sudan Min alhukum althunaee ela intifada Rajab. Khartoum. (Arabic Text)

25. Shinnie, P.L. (1979).The Nilotic Sudan and Ethiopia BC 666 AD 600. In J. D. Fage, Cambridge history of Africa, Cambridge, Cambridge University Press. 222-223

26. Warburg, Gabriel. (1971). The Sudan under Wingate: Administration in the Anglo- Egyptian Sudan (1899-1916). London, Frank Cass 